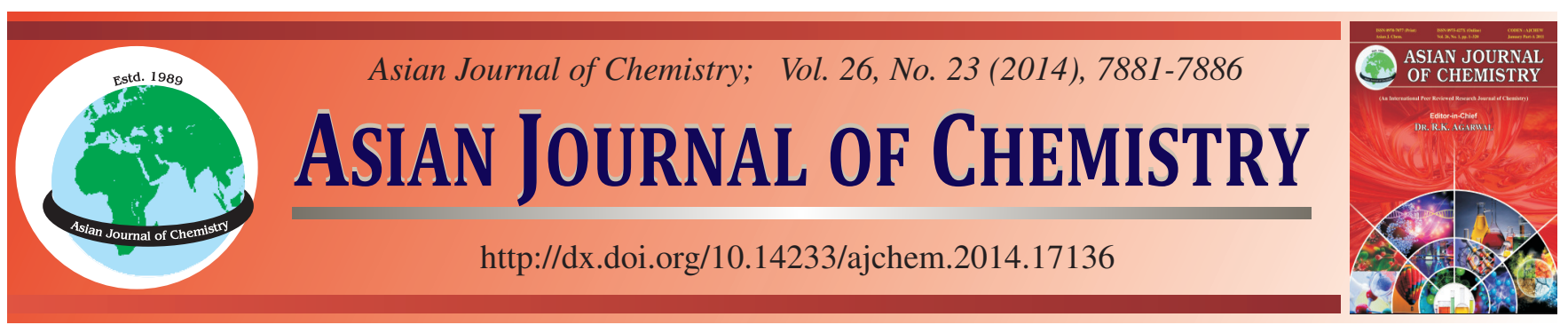

REVIEW

\title{
Removal Techniques of Nitrate from Water
}

\author{
Morteza Mohsenipour $^{1}$, Shamsuddin Shahid ${ }^{1, *}$ and Kumars Ebrahimi ${ }^{2}$
}

${ }^{1}$ Department of Hydraulics and Hydrology, Faculty of Civil Engineering Universiti Teknologi Malaysia, 81310 Johor Bahru, Malaysia ${ }^{2}$ Irrigation and Reclamation Engineering Department, University of Tehran, Tehran, Iran

*Corresponding author: E-mail: sshahid@utm.my

Received: 28 January 2014;

Accepted: 21 April 2014;

Published online: 15 November 2014;

AJC-16256

\begin{abstract}
Nitrate pollution of water is a major environmental problem all over the world. Consequently, numerous techniques have been developed to remove or reduction of nitrate in water. A review of removal techniques of nitrate from water has been carried out in this paper. Recent literatures related to various techniques including reverse osmosis, ion exchange, electrodialysis, biological denitrification, chemical denitrification, adsorption methods using different adsorbents like carbon base, agricultural waste, natural materials are systematically review to assess their performance. The paper reveals that adsorption could be the most promising technique of removal of nitrate from water in near future.
\end{abstract}

Keywords: Nitrate reduction, Reverse osmosis, Ion exchange, Electrodialysis, Denitrification, Adsorption.

\section{INTRODUCTION}

More than $70 \%$ of the area of earth is covered by water. Therefore, apparently it seems that earth is abundant with water. However, availability of fresh water is a major problem across the world. Only $3 \%$ of total water on the earth is useable. Out of this $3 \%$, nearly $70 \%$ of fresh water is frozen, $29 \%$ is present as soil moisture or lies in deep underground aquifers as groundwater and less than $1 \%$ of the world's fresh water is in the lakes and rivers ${ }^{1}$. However, it is regularly renewed by rain and snowfall and therefore, available on a sustainable basis. Safe drinking water is essential to humans and other life. Ever increasing demand increasing due to rapid population growth and dwindling supply of fresh water due to gradual destruct of fresh water resources have caused that water supplydemand balance in critical in many regions of the world. According to European Union ${ }^{3}$ water framework directives, a "pressure" is explained as an action that caused by human activities that have negative influence on water. The negative activities that cause the degradation of fresh water can be categorized into five types, such as point contamination sources, diffuse contamination sources, groundwater over exploitation, artificial recharge and seawater intrusion ${ }^{3}$ Among them, diffuse contamination due to human activities is a major cause of water pollution. Nitrate pollution of water due to intensive agricultural activities has become a major environmental problem since $1970 \mathrm{~s}^{4}$. Nitrate is highly soluble in water ${ }^{3}$ and does not readily bind to the soil causing it to be highly susceptible to leaching ${ }^{6}$. There are several potential sources of nitrate, including animal wastes, septic tanks, municipal wastewater treatment systems and decaying plant debris. However, nitrogenenriched fertilizers for farming are considered as the main source of nitrate pollution in the environment ${ }^{7}$.

To reduce the health hazard, a nitrate standard of $50 \mathrm{mg} / \mathrm{L}$ nitrate- $\mathrm{NO}_{3}{ }^{-}$or $10 \mathrm{mg} / \mathrm{L}$ nitrate- $\mathrm{N}$ in drinking water has been set by $\mathrm{WHO}^{8}$ and US EPA ${ }^{9}$. However, it has been reported that nitrate concentration in drinking water has exceeded from the maximum acceptable concentration in many parts of the globe ${ }^{10-12}$. Therefore, controlling nitrate level in potable water below the standard level has become a major concern. For instance, Defra ${ }^{13}$ estimated that UK government has been paid around $£$ G58 million per year by 2010 to keep the nitrate below permissible level in drinking water.

Numerous methods have been developed to reduce the nitrate concentration in water like reverse osmosis, ion exchange, electrodialysis, biological denitrification, chemical denitrification and adsorption ${ }^{14-21}$. All the methods have their inherent advantages and disadvantages. In the present study all the available methods are reviewed to assess their efficiency and economic suitability in removing nitrate from water. For this purpose, the recent literatures related to various nitrate removal techniques are systematically reviewed. It is expected that the study will help to enrich the knowledge of ongoing research on removal of nitrate from water. 
Popular methods of removal of nitrate: There are number of popular and conventional treatment technologies available for reduction or removal of nitrate in water such as reverse osmosis, ion exchange and electrodialysis, biological denitrification $^{22-27}$. These conventional methods are discussed below.

Reverse osmosis: Reverse osmosis (RO) was considered as $e x$ - and in situ applications for the reduction of nitrate from drinking water ${ }^{14,28,29}$. Reverse osmosis can be used to reduce a wide range of contaminants simultaneously ${ }^{20}$. The governing basic in reverse osmosis method is selectional passing. In other words, just water molecules are permitted to pass and leaving other ions by a semi-permeable membrane ${ }^{30}$. A single membrane of reverse osmosis can be uses to remove various contaminants viz. chloride, fluoride, sodium, etc. ${ }^{31}$. Contaminants are impeded by using pressure forces the water through membrane; therefore, solution concentration has direct relation to required pressure for feed water ${ }^{20}$. The solute removal efficiency in reverse osmosis method depends on initial solute concentration $^{32}$, however, the optimum nitrate reduction efficiency is $93 \%{ }^{15}$. Some different variables viz. initial nitrate concentration $^{32}$ and the material of membrane ${ }^{30}$ have negative effect on nitrate removal efficiency. The increasing of initial nitrate concentration from 25 to $200 \mathrm{mg} / \mathrm{L}$ causes decrease of removal efficiency $^{32}$ from 93.5 to $82.5 \%$.

Ion exchange: The governing basic in ion exchange (IX) method is generally substitute chloride anions with not desirable compound such as contaminants, total dissolve solids and so on. The process of nitrate reduction with ion exchange is similar to water softening, but the difference between them is polymer resin ${ }^{20}$. Nitrate pollutant from water is replaced with chloride by resin ${ }^{15}$. Eqn. 1 shows the reaction between nitrate pollutant and chloride on resin surface ${ }^{20}$.

$$
\mathrm{R}-\mathrm{Cl}+\mathrm{NO}_{3}^{-} \rightarrow \mathrm{R}-\mathrm{NO}_{3}+\mathrm{Cl}^{-}
$$

Exhausted resin of chloride is regenerated with a salt $(\mathrm{NaCl})$ rich brine solution which washes out the nitrate from resin surface and replaces with chloride again. Eqn. 2 shows the reaction between nitrate on resin surface and chloride from brine ${ }^{20}$.

$$
\mathrm{R}-\mathrm{NO}_{3}+\mathrm{Cl}^{-} \rightarrow \mathrm{R}-\mathrm{Cl}+\mathrm{NO}_{3}^{-}
$$

Various factors such as initial nitrate concentration, total dissolve solids, regenerator ${ }^{32}$, type of resin and other ions like sulfate $^{30}$ are reported that nitrate removal efficiency for initial nitrate concentration $25 \mathrm{mg} / \mathrm{L} \mathrm{NO}_{3}-\mathrm{N}$ and TDS $400 \mathrm{mg} / \mathrm{L}$ was $99.8 \%$ and nitrate removal efficiency for initial nitrate concentration 18-25 mg/L NO${ }_{3}-\mathrm{N}$ and TDS $530 \mathrm{mg} / \mathrm{L}$ and sulfate concentration $43 \mathrm{mg} / \mathrm{L}$ were between $45-60 \%{ }^{33}$.

Electro dialysis: Electric current is the governing basic in electro-dialysis method (ED) to remove or to reduce pollutants from water. The system consists of cathodic and anionic semi-permeable membrane and two electrodes. Electric current causes anions and cations in solution to move toward anode and cathode, respectively. During the experiment, ions trap in waste flow and leaving de-mineralized water behind ${ }^{20}$.

Reduction of inorganic pollutants like radium ${ }^{34}$, perchlorate $^{35}$, bromide ${ }^{36}$, fluoride ${ }^{19}$, iron and manganese ${ }^{37}$ and nitrate ${ }^{38}$ in drinking water were some applications of electro-dialysis. Pollutants removal efficiency of this method varies from 50 to $99 \%$ depending on pollution level ${ }^{39}$. For instance, electro-dialysis method reduced nitrate pollution from $42 \mathrm{mg} / \mathrm{L} \mathrm{NO}_{3}-\mathrm{N}$ to less than $10 \mathrm{mg} / \mathrm{L} \mathrm{NO}_{3}-\mathrm{N}$, in other words its efficiency is $76 \%{ }^{40}$.
Chemical dinitrification: Various chemical compounds have been used to reduce nitrate form contaminated water. Among those, the chemical compounds like zero-valent iron $^{21,41,42}$, nano-alumina ${ }^{17}$ and magnesium ${ }^{16,43}$ are most common. Description of different chemical dinitrification is given below.

Zero-valent iron: Since 1990s, contaminated groundwater with nitrate is treated using zero-valent iron as permeable reactive barrier ${ }^{44}$. Zero valent iron and nitrate have reaction together and redox is their reaction. The outputs of reactions are nitrite, nitrogen and ammonium which cause nitrate reduction $^{45}$. A number of researchers including Flis ${ }^{46}$, Huang \& Zhang $^{47}$ and $\mathrm{Su} \& \mathrm{Puls}^{48}$ mentioned different equations for nitrate reduction. For example, the eqns. 3 and 4 used to show the reaction between zero-valent iron and nitrate ${ }^{49}$.

$$
5 \mathrm{Fe}^{0}+2 \mathrm{NO}_{3}{ }^{-}+6 \mathrm{H}_{2} \mathrm{O} \rightarrow \mathrm{N}_{2}+5 \mathrm{Fe}^{2+}+12 \mathrm{OH}^{-}
$$$$
4 \mathrm{Fe}^{0}+\mathrm{NO}_{3}{ }^{-}+7 \mathrm{H}_{2} \mathrm{O} \rightarrow \mathrm{NH}_{4}{ }^{+}+4 \mathrm{Fe}^{2+}+10 \mathrm{OH}
$$

The range of nitrate removal efficiency in the solution depends on number of factors ${ }^{41}$ such as, $\mathrm{pH}^{50}$, nanoparticles size $^{44}$, method used of produce of nanoparticles ${ }^{45}$, the dose of nanoparticles to nitrate ${ }^{51}$ and contact time between particles and pollution ${ }^{21}$. For instance, the nitrate removal efficiency is $95 \%$ at $\mathrm{pH} 4$, contact time $60 \mathrm{~min}$, initial nitrate concentration $50 \mathrm{mg} / \mathrm{L}$ and nanoparticles concentration $15 \mathrm{~g} / \mathrm{L}^{21}$.

Zero-valent magnesium: Magnesium is one of metals which have been used to nitrate removal in solution for last many years.

It transforms the nitrate to nitrite and ammonia ${ }^{52}$. Eqns. 5-7 show the nitrate transform to nitrite and ammonium ${ }^{43}$.

$$
\begin{aligned}
& \mathrm{Mg}^{0}+\mathrm{NO}_{3}^{-}+2 \mathrm{H}^{+} \rightarrow \mathrm{NO}_{2}^{-}+\mathrm{Mg}^{2+}+\mathrm{H}_{2} \mathrm{O} \\
& 15 \mathrm{Mg}^{0}+2 \mathrm{NO}_{3}^{-}+12 \mathrm{H}^{+} \rightarrow \mathrm{N}_{2}+2 \mathrm{Mg}^{2+}+5 \mathrm{H}_{2} \mathrm{O} \\
& 4 \mathrm{Mg}_{0}+\mathrm{NO}_{3}^{-}+10 \mathrm{H}^{+} \rightarrow \mathrm{NH}_{4}^{+}+4 \mathrm{Mg}^{2+}+3 \mathrm{H}_{2} \mathrm{O}
\end{aligned}
$$

Various factors affect the efficiency of nitrate reduction in aqueous phase using zero-valent magnesium ${ }^{16}$. Equilibrium condition happen in short time and the rate of denitrification depend on contact time, initial nitrate concentration, the ratio of magnesium to nitrate and magnesium dose ${ }^{43}$. For example, the nitrate removal efficiency is $93 \%$ at $\mathrm{pH}$ 2, contact time 20 min, initial nitrate concentration $50 \mathrm{mg} / \mathrm{L}$ and nanoparticles concentration $2 \mathrm{~g} / \mathrm{L}^{16}$.

Zero-valent alumina: Contaminated water with nitrate was treated using alumina powder by Murphy ${ }^{53}$ and, Bhatnagar $\&$ Sillanpaa ${ }^{17}$. Principal product of nitrate reduction by this method is ammonia with some nitrite and nitrogen ${ }^{52}$. Eqns. 810 show nitrate transformation by zero-valent alumina.

$$
\begin{aligned}
& 2 \mathrm{Al}+3 \mathrm{NO}_{3}^{-}+3 \mathrm{H}_{2} \mathrm{O} \rightarrow 3 \mathrm{NO}_{2}^{-}+2 \mathrm{Al}(\mathrm{OH})_{3} \\
& 2 \mathrm{Al}+\mathrm{NO}_{2}^{-}+5 \mathrm{H}_{2} \mathrm{O} \rightarrow \mathrm{NH}_{3}+2 \mathrm{Al}(\mathrm{OH})_{3}+\mathrm{OH}^{-} \\
& 2 \mathrm{Al}+2 \mathrm{NO}_{2}^{-}+4 \mathrm{H}_{2} \mathrm{O} \rightarrow \mathrm{N}_{2}+2 \mathrm{Al}(\mathrm{OH})_{3}+2 \mathrm{OH}^{-}
\end{aligned}
$$

In contrast to magnesium and iron nitrate reduction, this method reaches a maximum at $\mathrm{pH} 10.5^{52,53}$. Nitrate removal efficiency by this method is also depends on various factors which effect nitrate reduction between 60-95 \% $\%^{53}$.

Biological denitrification: Nitrate reduction to harmless nitrogen in special absence oxygen condition is the governing principle of biological denitrification $(B D)^{20}$. Nitrate is used as terminal electron acceptor in the respiratory process by bacteria when oxygen is absent ${ }^{26}$. The reduction of nitrate to nitrogen are done in four steps as shown in eqn. $11^{54}$.

$$
\mathrm{NO}_{3}{ }^{-} \rightarrow \mathrm{NO}_{2}{ }^{-} \rightarrow \mathrm{NO} \rightarrow \mathrm{N}_{2} \mathrm{O} \rightarrow \mathrm{N}_{2}
$$


Facultative anaerobes carry out biological denitrification which can be organic or inorganic ${ }^{55,56}$. Heterotrophs and autotrophs are two major groups of denitrifiers. The difference between them is the way to get substance as energy source which heterotrophs need to organic and autotrophs need to inorganic substance ${ }^{57}$. Denitrification rate depends on the type and concentration of carbon ${ }^{58,59}$ as well as carbon to nitrogen $(\mathrm{C} / \mathrm{N})$ ratio $^{56}$. Nitrate removal reported the efficiency of biological denitrification method with nitrate-degrading bacteria Pseudomonas and carbon source starch $1 \%$ for initial nitrate concentration 500 and $460 \mathrm{mg} / \mathrm{L}$ are 86 and $89 \%$, respectively $^{60}$.

Summary of popular methods: According to previous reports $^{22,25,26}$ ion exchange, electordialysis and reverse osmosis are the most valuable methods to reduce nitrate in water. However, they have number of disadvantages and limitations which are discussed below.

(1) Nitrate removal using reverse osmosis suffers from fouling, compaction and deterioration with time ${ }^{30}$, energy demand, waste disposal ${ }^{20,61}$, concentrated waste brine and high $\cos ^{23,24}$. Furthermore, its efficiency is not satisfactory if the feed water quality is very low ${ }^{20}$.

(2) Nitrate removal with the ion-exchange method is not a suitable for the water with high $\operatorname{TDS}^{40}$. Ion-exchange method may release nitrate in environment during resin regeneration ${ }^{24}$.

(3) Electrodialysis method has number of limitations including high system complexity, energy demand, waste disposal $^{20,61}$, difficult operation and maintain in rural areas ${ }^{40}$.

(4) Biological denitrifications are potentially more complex. This type of method suffers from number of disadvantages such as high monitoring needs, sensitivity to environmental conditions and risk of nitrite formation ${ }^{20,61}$.

(5) Ammonia and nitrogen gas are undesired products of using metallic zero valent methods ${ }^{62}$.

Comparison of various properties viz., reliability, maintenance, cost, operation, etc. of different methods is shown in Table- 1 .

Limitations of different conventional methods led to more research on removal techniques of nitrate. New approach based on adsorption technique is proposed to reduce or omit those limitations in conventional treatment methods.
Adsorption: Convenience, no difficulty of process, low cost and ease of plan are the main advantages of adsorption method for water treatment ${ }^{17}$. Various inorganic contaminants viz., fluoride ${ }^{63}$, nitrate $^{64}$, bromate ${ }^{65}$, perchlorate ${ }^{66}$ etc. are removed or reduced using different type of adsorbents. Adsorbents can be categorized in to six groups namely, carbon base, natural, agricultural wastes, industrial wastes, biosorbent and miscellaneous ${ }^{6}$.

Carbon base adsorbents: Carbon base group absorbents includes powdered activated carbon, carbon cloth, carbon nanotubes, commercial activated carbon, zinc chloride treated granular activated carbon and iron oxide-dispersed activated carbon fiber. Although different types of organic contaminants are removed sufficiently by using activated carbon, efficiency of activated carbon in ionic adsorption is poor. Modified carbon cloth used for nitrate removal and reported that adsorption of modified carbon cloth with sulfuric acid for nitrate was 2.03 $\mathrm{mmol} / \mathrm{g}$ which was too high compared to non treated carbon ${ }^{6,67}$. Khani and Mirzaei ${ }^{68}$ used powdered activated carbon and carbon nanotubes for pollution reduction of nitrate and reported the adsorptions were 10 and $25 \mathrm{mmol} / \mathrm{g}$, respectively. Nonactivated granular carbon, produce by coconut shells and activated with zinc chloride showed reduction of nitrate with adsorption capacity 1.7 and $10.2 \mathrm{mg} / \mathrm{L}$, respectively ${ }^{69}$. The adsorption of nitrate has been studied using bamboo powder charcoal by ${ }^{70}$ and reported upto $1.25 \mathrm{mg} / \mathrm{g}$ of nitrate removal.

Natural adsorbents: Natural adsorbents include clay, zeolite and sepiolite ${ }^{6}$ and leonardite ${ }^{71}$. Contaminants are reduced through ion exchange or adsorption by clays as natural scavengers. A comprehensive study investigated on the effect of different types of row clay, montmorillonite, kaolinite and illite on nitrate mobility in unsaturated zone $\mathrm{e}^{72,73}$. The results showed that anion adsorption is domain in kaolinite-sand mixture. Calcium montmorrillonite modified by hydrochloric acid have more removal efficiency of nitrate, up to $22.28 \%$, than that modified by sulfuric acid although untreated bentonite, kaolinite and halloysite have poor nitrate adsorption, their nitrate removal capability increase if modified ${ }^{66,74}$. Nitrate adsorption also have direct relation to the concentration of modifier ${ }^{66}$. Modified and unmodified sepiolite are used to nitrate removal from water. Dodecyl ethyl dimethyl ammonium

TABLE-1

GENERAL COMPARISION BETWEEN DIFFERENT METHODS [AFTER SEIDEL et al..$^{20}$ ]

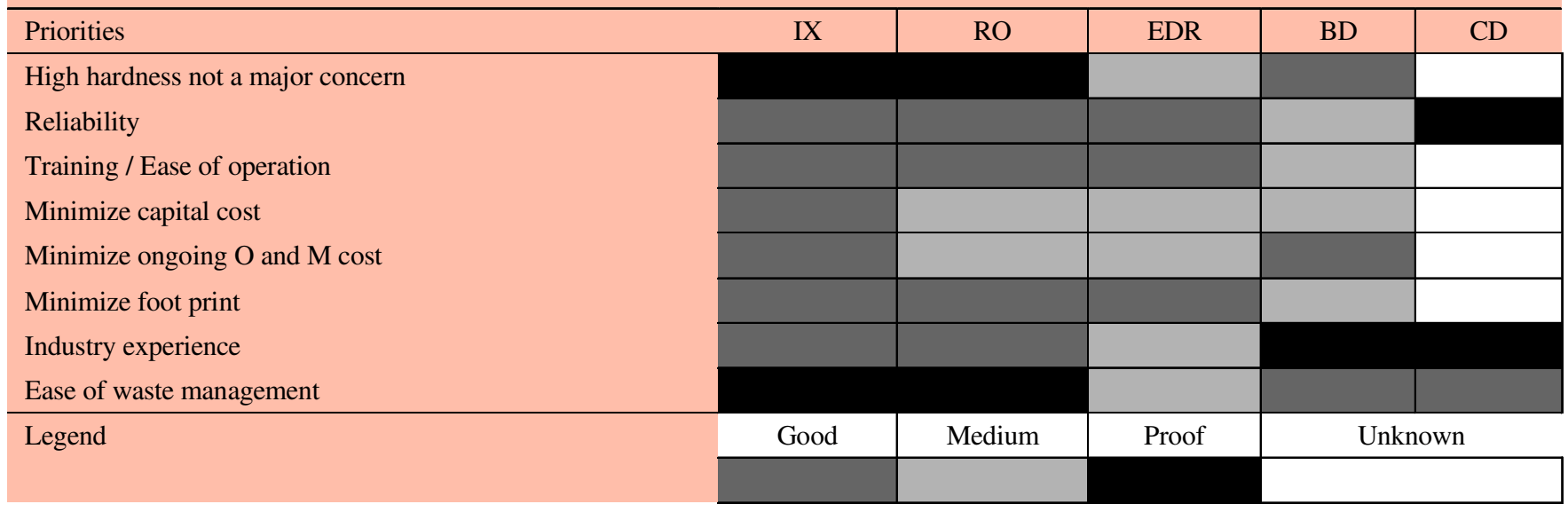


(DEDMA) bromide was used by Ozcan et al. ${ }^{75}$ to sepiolite modification. Results showed nitrate reduction efficiency in both of adsorbents and modified sepiolite are significantly more than unmodified sepilite ${ }^{76}$. Investigated nitrate reduction using natural and modified zeolite. Various variables such as $\mathrm{pH}$, temperature, adsorbent dosage, other ions and the amount of surfactant were tested on nitrate removal. Except $\mathrm{pH}$ and temperature other variable are found to have effect on removal of nitrate. The removal efficiencies of nitrate in groundwater using unmodified and modified zeolite are reported as 5 and $77 \%$, respectively. The result of nitrate reduction using raw zeolite showed that it is not suitable for water treatment. A comprehensive study is conducted on removal of nitrate from groundwater by using modified zeolite ${ }^{77-80}$. Hexadecyltrimethyl ammonium bromide was used to modify natural zeolite. The effect of different variables such as the amount of adsorbent, temperature and the amount of hexadecyltrimethyl ammonium bromide for modified natural zeolite are investigated. The results showed nitrate adsorption is significant by using modified zeolite. Nitrate removal evaluated from aqueous solution using sulfuric acid modified by leonadite ${ }^{71}$. The maximum nitrate removal of $77 \%$ is found with $\mathrm{pH}$ equals to 5 , contact time $1 \mathrm{~h}$, initial nitrate concentration $50 \mathrm{mg} / \mathrm{L}$ and the dosage of adsorbent $1 \mathrm{~g}$.

Agricultural wastes adsorbents: Agricultural wastes are included in different varieties of plants such as wheat straw, sugarcane bagasse, rice hull, coconut shells, almond shell and sugar beet pulp. The removal of nitrate has been conducted using modified and unmodified agricultural waste by some researchers. A series of experimental tests conducted on modified and unmodified almond shell. $\mathrm{Zn}^{0}$ and $\mathrm{ZnSO}_{4}$ are used for modification. Results showed the removal efficiency of nitrate for modified almond shell are better than unmodified almond shell. Evaluation of nitrate removal showed $64-80$ and 5-42 \% for modified almond with $\mathrm{Zn}^{0}$ and $\mathrm{ZnSO}_{4}$, respectively. The removal of nitrate from aqueous solution has been carried out ${ }^{81}$ using modified and unmodified wheat straw that passed through a fine-mesh sieve. Epichlorohydrin and dimethylamine are crosslinked with raw wheat straw to make modified adsorbent. The results showed the maximum nitrate adsorption in aqueous solution using modified wheat straw is $2.08 \mathrm{mmol} / \mathrm{g}$. Nitrate and sulfate adsorption evaluated in water using modified sugar beet pulp ${ }^{82}$. Zirconium(IV) ion was used to preparation modified adsorbent. Various variables such as contact time, anions concentration, temperature and $\mathrm{pH}$ are used to investigation the effect on the adsorption capacity. It was reported that 114 and $63 \mathrm{mg} / \mathrm{g}$ are the maximum adsorption capacity of modified adsorbent for sulfate and nitrate respectively. Raw wheat and mustard straw charcoal were used to assess nitrate reduction from water by Mishra and Patel ${ }^{83}$. The maximum calculated values of adsorbents are reported as 1.10 and $1.30 \mathrm{mg} / \mathrm{g}$, respectively. Sugar beet bagasse was modified using $\mathrm{ZnCl}_{2}$ for removal of nitrate ${ }^{84}$. They reported that temperature and $\mathrm{pH}$ are two most influence factors on nitrate removal. The maximum nitrate reduction was $41.2 \%$ at $\mathrm{pH}$ equals to 3 . The adsorption capacity raised from 9.14 to $27.55 \mathrm{mg} / \mathrm{g}$ when temperature changed from 25 to $45^{\circ} \mathrm{C}$. Nitrate adsorption assessed using modified beet residue ${ }^{85}$. The adsorbent wad modified using epichlorohydrin and pyridine. The results showed adsorbent caused nitrate reduction more than $90 \%$.
Other adsorbents: Industrial wastes, biosorbent and miscellaneous are different adsorbents that have been studied in few cases by different researchers. The removal of nitrate studied from water by red mud in both active and non-active conditions $^{86}$. A batch experiment tests carried out to study the removal of nitrate from aqueous solution. Different conditions such as different $\mathrm{pH}$, contact time between adsorbent and contamination and the dosage of adsorbent were investigated. The results showed the capacity of active red mud for nitrate adsorption was more than the original red mud which was about three times, 1.859 and $5.858 \mathrm{mmol} / \mathrm{g}$ for non-active and active re mud, respectively. Chitosan can be considered as an adsorbent because of the presence of amino and hydroxyl functional in $\mathrm{it}^{87}$. The use of chitosan examined in nitrate removal from water ${ }^{88}$. They reported temperature and $\mathrm{pH}$ are two variables which had effect on nitrate adsorption. The maximum nitrate adsorption was found $92.1 \mathrm{mg} / \mathrm{g}$ at $30^{\circ} \mathrm{C}$. According to Islam and Patel $^{89}$, layered-double hydroxides are inorganic material which tends to remove anionic contaminants from water. Layered-double hydroxides are made with various diffe-

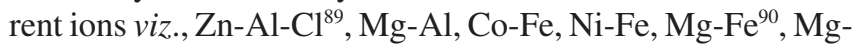
$\mathrm{Al}-\mathrm{Cl}^{91-94}$ and so on. Nitrate removal by this method is relatively high. For example, $\mathrm{Zn}-\mathrm{Al}-\mathrm{Cl}$, and $\mathrm{Mg}-\mathrm{Al}-\mathrm{Cl}$ can remove upto 85.5 and $87.6 \%$ nitrate, respectively ${ }^{92}$. Some other adsorbents have been proposed by researchers to adsorb nitrate from aqueous solution. Characteristics of those adsorbents are summarized in Table-2.

\section{Conclusion}

Ever increasing of nitrate in aqueous media and its adverse effect on human health and ecology has led intensive research on cost effective and efficient nitrate removal techniques. Consequently, numerous methods have been developed for nitrate removal. The review of the methods indicates that Ion exchange, reverse osmosis, Biological denitrification and electrodialysis are the most effective methods of nitrate removal from water. However, the major limitation of these methods is the disposal concentrated waste stream to environment and risk of nitrite formation (potential incomplete denitrification). Adsorption methods absorb pollutant therefore are free from some limitations; however, the full scale application of adsorption options is currently limited.

\section{ACKNOWLEDGEMENTS}

The authors acknowledge to Ministry of Education Malaysia and Universiti Teknologi Malaysia (UTM) to support this research using ERGS grant number R.J130000.7822.4L084.

\section{REFERENCES}

1. Z.A. Amin, The Water Problem. Retrieved on October 21, 2013. From www.globalpolicy.org/component/content/article/198/40385.html (2007).

2. European Union, Water Framework Directive, Directive 2000/60/CE of the European Parliament and of the Council of 23 October 2000, Establishing a Framework for Community Action in the Field of Water Policy, DO L 327 of 22 December (2000).

3. C. Martínez-Navarrete, A. Jiménez-Madrid, I. Sánchez-Navarro, F. CarrascoCantos and L. Moreno-Merino, Int. J. Water Resour. Dev., 27, 227 (2011).

4. M.O. Rivett, S.R. Buss, P. Morgan, J.W.N. Smith and C.D. Bemment, Water Res., 42, 4215 (2008).

5. T.S. Thompson, Bull. Environ. Contam. Toxicol., 66, 64 (2001). 


\begin{tabular}{|c|c|c|c|c|c|c|c|}
\hline \multicolumn{8}{|c|}{$\begin{array}{c}\text { TABLE-2 } \\
\text { OPTIMUM PARAMETERS FOR VARIOUS ADSORBENT: USED FOR } \\
\text { NITRATE REMOVAL (AFTER BHATNAGAR AND SILLANPAA, } 2011\end{array}$} \\
\hline$\#$ & Adsorbent & $\begin{array}{l}\text { Amount } \\
\text { adsorbed }\end{array}$ & $\begin{array}{l}\text { Concentration } \\
\text { range }(\mathrm{mg} / \mathrm{L})\end{array}$ & $\begin{array}{l}\text { Contact } \\
\text { time }\end{array}$ & Temperature & $\mathrm{pH}$ & Refrence \\
\hline 1 & $\mathrm{H}_{2} \mathrm{SO}_{4}$ Treated carbon cloth & $2.03 \mathrm{mmol} / \mathrm{g}$ & 115 & $60 \mathrm{~min}$ & $25{ }^{\circ} \mathrm{C}$ & 7.0 & 67 \\
\hline 2 & Powdered activated carbon & $10 \mathrm{mmol} / \mathrm{g}$ & - & $60 \mathrm{~min}$ & $25^{\circ} \mathrm{C}$ & $<5.0$ & 68 \\
\hline 3 & Carbon nanotubes & $25 \mathrm{mmol} / \mathrm{g}$ & - & $60 \mathrm{~min}$ & $25{ }^{\circ} \mathrm{C}$ & $<5.0$ & 68 \\
\hline 4 & Untreated coconut granular activated carbon & $1.7 \mathrm{mg} / \mathrm{g}$ & $5-200$ & $2 \mathrm{~h}$ & $25^{\circ} \mathrm{C}$ & 5.5 & 69 \\
\hline 5 & $\begin{array}{l}\mathrm{ZnCl}_{2} \text { treated coconut granular } \\
\text { activated carbon }\end{array}$ & $10.2 \mathrm{mg} / \mathrm{g}$ & $5-200$ & $2 \mathrm{~h}$ & $25^{\circ} \mathrm{C}$ & 5.5 & 69 \\
\hline 6 & Coconut shell activated carbon & $2.66 \times 10^{-1} \mathrm{mmol} / \mathrm{g}$ & - & - & $303 \mathrm{~K}$ & $2-4$ & 96 \\
\hline 7 & Bamboo charcoal & $1.04 \times 10^{-1} \mathrm{mmol} / \mathrm{g}$ & - & - & $303 \mathrm{~K}$ & $2-4$ & 96 \\
\hline 8 & Bamboo powder charcoal & $1.25 \mathrm{mg} / \mathrm{g}$ & $0-10$ & $120 \mathrm{~h}$ & $10{ }^{\circ} \mathrm{C}$ & & 70 \\
\hline 9 & Halloysite & $0.54 \mathrm{mg} / \mathrm{g}$ & 100 & $17 \mathrm{~h}$ & $\begin{array}{l}\text { Room } \\
\text { temperature }\end{array}$ & 5.4 & 66 \\
\hline 10 & HDTMA modified QLD-bentonite & $12.83-14.76 \mathrm{mg} / \mathrm{g}$ & 100 & $17 \mathrm{~h}$ & $\begin{array}{l}\text { Room } \\
\text { temperature }\end{array}$ & 5.4 & 66 \\
\hline 11 & Calcined hydrotalcite-type compounds & $61.7-147.0 \mathrm{~g} / \mathrm{kg}$ & $12.7-236$ & $24 \mathrm{~h}$ & $25^{\circ} \mathrm{C}$ & & 97 \\
\hline 12 & Layered double hydroxides & $20-35 \mathrm{mg} / \mathrm{g}$ & $0-1000$ & $4 \mathrm{~h}$ & $21{ }^{\circ} \mathrm{C}$ & 8.5 & 93 \\
\hline 13 & Chitosan coated zeolite & $0.6-0.74 \mathrm{mmol} / \mathrm{g}$ & $10-3100$ & $72 \mathrm{~h}$ & 4 and $20^{\circ} \mathrm{C}$ & & 98 \\
\hline 14 & Chitosan hydrobeads & $92.1 \mathrm{mg} / \mathrm{g}$ & $1-1000$ & $1440 \mathrm{~min}$ & $30^{\circ} \mathrm{C}$ & 5.0 & 89 \\
\hline 15 & Chitosan beads & $90.7 \mathrm{mg} / \mathrm{g}$ & $25-1000$ & $24 \mathrm{~h}$ & $30{ }^{\circ} \mathrm{C}$ & 5.0 & 89 \\
\hline 16 & Conditioned cross-linked chitosanbeads & $104.0 \mathrm{mg} / \mathrm{g}$ & $25-1000$ & $24 \mathrm{~h}$ & $30^{\circ} \mathrm{C}$ & 5.0 & 89 \\
\hline 17 & Pure alkaline lignin & $1.8 \mathrm{mmol} / \mathrm{g}$ & $1-30$ & $48 \mathrm{~h}$ & $30{ }^{\circ} \mathrm{C}$ & - & 99 \\
\hline 18 & Sugarcane bagasse & $1.41 \mathrm{mmol} / \mathrm{g}$ & $1-30$ & $48 \mathrm{~h}$ & $30{ }^{\circ} \mathrm{C}$ & - & 99 \\
\hline 19 & Pure cellulose & $1.34 \mathrm{mmol} / \mathrm{g}$ & $1-30$ & $48 \mathrm{~h}$ & $30^{\circ} \mathrm{C}$ & - & 99 \\
\hline 20 & Rice hull & $1.32 \mathrm{mmol} / \mathrm{g}$ & $1-30$ & $48 \mathrm{~h}$ & $30{ }^{\circ} \mathrm{C}$ & - & 99 \\
\hline 21 & Raw wheat residue & $0.02 \mathrm{mmol} / \mathrm{g}$ & $50-500$ & $150 \mathrm{~min}$ & $23 \pm 2{ }^{\circ} \mathrm{C}$ & 6.8 & 68 \\
\hline
\end{tabular}

6. A. Bhatnagar and M. Sillanpaa, Chem. Eng. J., 168, 493 (2011).

7. S. Suthar, P. Bishnoi, S. Singh, P.K. Mutiyar, A.K. Nema and N.S. Patil, Indian J. Hazard. Mater., 171, 189 (2009).

8. WHO, Guidelines for Drinking Water Quality, Recommendations, World Health Organisation, Geneva, Vol. I (1984).

9. EPA, Quality Criteria for Water, USA Environmental Protections Authority, Washington D.C., USA (1986).

10. F. Lasserre, M. Razack and O. Banton, J. Hydrol., 224, 81 (1999).

11. M. de Wit and G. Bendoricchio, Sci. Total Environ., 273, 147 (2001).

12. J. Garnier, J. Nemery, G. Billen and S. Thery, J. Hydrol., 304, 397 (2005).

13. Department for Environment, Food and Rural Affairs (Defra), Postconciliation Partial Regulatory Impact Assessment.Groundwater Proposals under Article 17 of the Water Framework Directive. Draft final report. London: Defra (2006).

14. K.J. Howe. Technical Challenges to Concentrate Disposal from Inland Desalination. The University of New Mexico, Department of Civil Engineering. In: Proceedings Identifying Technologies to Improve Regional Water Stewardship: A Conference Series Featuring Intersections of Technology and Water Management North- Middle Rio Grande Corridor (2004).

15. D. Elyanow and J. Persechino, Advances in Nitrate Removal, GE General Electric Company, Water \& Process Technologies. Retrieve on June 11, 2013 from http://www.gewater.com/pdf/Technical\%20PapersCust/Americas/English/TP1033EN.pdf (2005).

16. M. Kumar and S. Chakraborty, J. Hazard. Mater., 135, 112 (2006).

17. A. Bhatnagar and M. Sillanpaa, Chem. Eng. J., 157, 277 (2010).

18. A. Bhatnagar, E. Kumar and M. Sillanpää, Chem. Eng. J., 163, 317 (2010).

19. F. Valero, A. Barceló and R. Arbós, in ed.: M. Schorr, Electrodialysis Technology-Theory and Applications, In: Desalination, Trends and Technologies, InTech, Croatia (2011).

20. C. Seidel, C. Gorman, J.L. Darby and V.B. Jensen, An Assessment of the State of Nitrate Treatment Alternative. Final Report, American Water Works Association Inorganic Contaminant Research and Inorganic Water Quality Joint Project Committees (2011).

21. M. Malakootian, K.Yaghmaian and M. Tahergorabi, J. Hygiene Rise, 10, 35 (2012).

22. S. Islam and M.T. Suidan, Water Res., 32, 528 (1998)

23. S.J. Ergas and A.F. Reuss, J. Water Supply Res. Technol., 50, 161 (2001).

24. M. Shrimali and K.P. Singh, Environ. Pollut., 112, 351 (2001).

25. Z. Feleke and Y. Sakakibara, Water Res., 36, 3092 (2002).
26. M. Prosnansky, Y. Sakakibara and M. Kuroda, Water Res., 36, 4801 (2002).

27. K.S. Haugen, M.J. Semmens and P.J. Novak, Water Res., 36, 3497 (2002).

28. J.N. Cevaal, W.B. Suratt and J.E. Burke, Desalination, 103, 101 (1995).

29. J. Black. Treasure from the Deep: Drinking Water. Retrieved on May 1, 2013 from http://www.businessweek.com/stories/2003-04-30/treasure-from-the-deep-drinking-water.

30. A. Kapoor and T. Viraraghavan, J. Environ. Eng., 123, 371 (1997).

31. B.I. Dvorak and S.O. Skipton, Drinking Water Treatment: Reverse Osmosis, NebGuide, University ofNebraska, Lincoln. Retrieved on April 25, 2008. From <http://www.ianrpubs.unl.edu/epublic/live/g1490/build/ g1490.pdf>

32. A. Torabian, A.H. Hasani, M. Sammak Abedi, Sci. Environ. Technol., 8, 21 (2006).

33. D. Clifford, C.-C. Lin, L.-L. Horng and J. Boegel, Nitrate Removal from Drinking Water in Glendale,Arizona. USEPA, EPA-600/S2-86/ 107 (1987).

34. J. Hays, Desalination, 132, 161 (2000).

35. V. Roquebert, S. Booth, R.S. Cushing, G. Crozes and E. Hansen, Desalination, 131, 285 (2000).

36. F. Valero and R. Arbós, Desalination, 253, 170 (2010).

37. D. Heshka, Desalination, 88, 109 (1992).

38. M.A. Menkouchi Sahli, S. Annouar, M. Mountadar, A. Soufiane and A. Elmidaoui, Desalination, 227, 327 (2008).

39. American Water Works Association (AWWA), Electrodialysis and Electrodialysis Reversal. Manual of Water Supply Practices - M38, First Edition, AWWA, Denver, Colorado (1995).

40. J.J. Schoeman, Water S.A., 35, 721 (2009).

41. C.-P. Huang, H.-W. Wang and P.C. Chiu, Water Res., 32, 2257 (1998).

42. Y.H. Huang and T.C. Zhang, Water Res., 38, 2631 (2004).

43. B. Mortazavi, B. Ramavandi and G.R. Mousavi, J. Health Environ., 3, 11 (2010).

44. X.D. Li, W. Elliott and X.W. Zhang, Crit. Rev. Solid State Mater. Sci., 31, 111 (2006)

45. M.Z. Kassaee, E. Motamedi, A. Mikhak and R. Rahnemaie, Chem. Eng. J., 166, 490 (2011).

46. J. Flis, Mater. Sci. Monograph, 59, 57 (1991).

47. Y.H. Huang and T.C. Zhang, J. Environ. Eng., 128, 604 (2002).

48. C.M. Su and R.W. Puls, Environ. Sci. Technol., 38, 2715 (2004).

49. B.A. Till, L.J. Weathers and P.J. Alvarez, Environ. Sci. Technol., 32, 634 (1998). 
50. Z. Jiang, L. Lv, W. Zhang, Q. Du, B. Pan, L. Yang and Q. Zhang, Water Res., 45, 2191 (2011).

51. G.C. Yang and H.L. Lee, Water Res., 39, 884 (2005).

52. J.C. Fanning, Coord. Chem. Rev., 199, 159 (2000).

53. A.P. Murphy, Nature, 350, 223 (1991).

54. S. Ghafari, M. Hasan and M.K. Aroua, Bioresour. Technol., 99, 3965 (2008).

55. K.L. Cast and J.R.V. Flora, Water Res., 32, 63 (1998).

56. J. van Rijn, Y. Tal and H.J. Schreier, Aquacult. Eng., 34, 364 (2006).

57. Y. Zhao, C. Feng, Q. Wang, Y. Yang, Z. Zhang and N. Sugiura, J. Hazard. Mater., 192, 1033 (2011).

58. J.M. Galvez, M.A. Gomez, E. Hontoria and J. Gonzalez-Lopez, J. Hazard. Mater, 101, 219 (2003).

59. M.A. Gomez, J.M. Galvez, E. Hontoria and J. Gonzalez-Lopez, J. Biosci. Bioeng., 95, 245 (2003).

60. Y.H. Kim, E.D. Hwang, W.S. Shin, J.H. Choi, T.W. Ha and S.J. Choi, Desalination, 202, 286 (2007).

61. Washington State Department of Health (WA DOH), Guidance Document: Nitrate Treatment Alternatives for Small Water Systems, DOH PUB. No. 331-309 (2005).

62. S. Biswas and P. Bose, J. Environ. Eng., 131, 1212 (2005).

63. T. Wajima, Y. Umeta, S. Narita and K. Sugawara, Desalination, 249, 323 (2009).

64. C. Namasivayam and D. Sangeetha, Indian J. Chem. Technol., 12, 513 (2005).

65. W.J. Huang and Y.L. Cheng, Sep. Sci. Technol., 59, 101 (2008).

66. Y. Xi, M. Mallavarapu and R. Naidu, Appl. Clay Sci., 48, 92 (2010).

67. A. Afkhami, T. Madrakian and Z. Karimi, J. Hazard. Mater., 144, 427 (2007).

68. A. Khani and M. Mirzaei, Comparative Study of Nitrate Removal from Aqueous Solution Using Powder Activated Carbon and Carbon Nanotubes, Proceedings on the 2nd International IUPAC Conference on Green Chemistry, Russia, pp. 14-19 (2008).

69. A. Bhatnagar, M. Ji, Y.H. Choi, W. Jung, S.H. Lee, S.J. Kim, G. Lee, H. Suk, H.S. Kim, B. Min, S.H. Kim, B.H. Jeon and J.W. Kang, Sep. Sci. Technol., 43, 886 (2008).

70. K. Mizuta, T. Matsumoto, Y. Hatate, K. Nishihara and T. Nakanishi, Bioresour. Technol., 95, 255 (2004).

71. E. Naderi, K. Farhadi, H. Pirkharati and B. Dolati, Nitrate Removal in Aqueous Solution using Modified Leonardite, Proceedings of $31^{\text {st }}$ Conference on the Geology Science, December, Tehran, Iran (2012).
72. K.G. Bhattacharyya and S.S. Gupta, Adv. Colloid Interf. Sci., 140, 114 (2008).

73. B.J. Allred, J.M. Bigham and G.O. Brown, Vadose Zone J., 6, 221 (2007).

74. C.J. Mena-Duran, M.R. Sun Kou, T. Lopez, J.A. Azamar-Barrios, D.H. Aguilar, M.I. Domínguez, J.A. Odriozola and P. Quintana, Appl. Surf. Sci., 253, 5762 (2007).

75. A. Ozcan, M. Sahin and A.S. Ozcan, Adsorpt. Sci. Technol., 23, 323 (2005).

76. M.S. Onyango, M. Masukume, A. Ochieng and F. Otieno, Water S.A., 36, 655 (2010).

77. J. Schick, P. Caullet, J.-L. Paillaud, J. Patarin and C. Mangold-Callarec, Micropor. Mesopor. Mater., 132, 395 (2010).

78. A. Mazeikiene, M. Valentukeviciene, M. Rimeika, A.B. Matuzevicius and R. Dauknys, J. Environ. Eng. Landscape Manage., 16, 38 (2008).

79. Z. Li and R.S. Bowman, Water Res., 35, 322 (2001).

80. M. Masukume, M.S. Onyango, O. Aoyi and F. Otieno, Nitrate Removal from Groundwater using Modified Natural Zeolite; Retrieve on August 26, 2013 from http://www.ewisa.co.za/literature/files/144_97\% 20 Masukume.pdf (2010).

81. Y. Wang, B. Gao, W. Yue and Q. Yue, J. Environ. Sci. (China), 19, 1305 (2007).

82. M.L. Hassan, N.F. Kassem and A.H. Abd El-Kader, J. Appl. Polym. Sci., 117, 2205 (2010)

83. P.C. Mishra and R.K. Patel, J. Environ. Manage., 90, 519 (2009).

84. H. Demiral and G. Gunduzoglu, Bioresour. Technol., 101, 1675 (2010).

85. M. Karimi, M.H. Entezari and M. Chamsaz, Ultrason. Sonochem., 17, 711 (2010).

86. Y. Cengeloglu, A. Tor, M. Ersoz and G. Arslan, Sep. Purif. Technol., 51, 374 (2006).

87. A. Bhatnagar and A. Sillanpaa, Adv. Colloid Interf. Sci., 152, 26 (2009).

88. S. Chatterjee and S.H. Woo, J. Hazard. Mater., 164, 1012 (2009).

89. M. Islam and R. Patel, Desalination, 256, 120 (2010).

90. S. Tezuka, R. Chitrakar, A. Sonoda, K. Ooi and T. Tomida, Green Chem., 6, 104 (2004)

91. M. Islam and R. Patel, J. Hazard. Mater., 169, 524 (2009).

92. K. Hosni and E. Srasra, Inorg. Mater., 44, 742 (2008).

93. A. Rezaee, H. Godini, S. Dehestani and A. Khavanin, Iran. J. Environ. Health Sci. Eng., 5, 125 (2008).

94. Y. Xie, S. Li, F. Wang and G. Liu, Chem. Eng. J., 156, 56 (2010). 